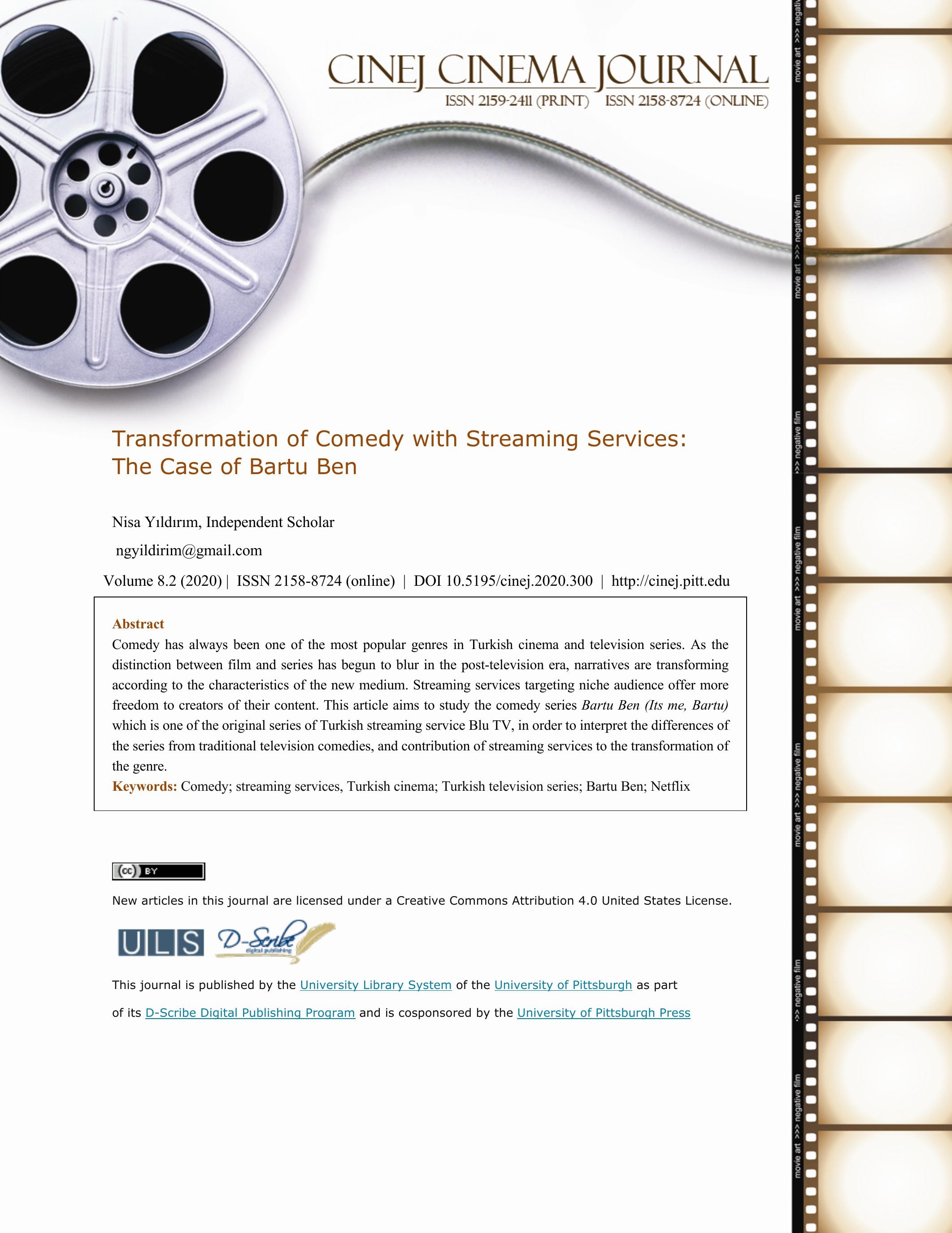




\section{Transformation of Comedy with Streaming Services: The Case of Bartu Ben \\ Nisa Yıldırım}

\section{Introduction}

In the recent era, the distinction between cinematic and televisual narratives has been blurring due to the evolution of these two media with the impact of digital technologies. Streaming services have been threatening cinema and television lately in terms of both production and distribution by creating their original films and series, besides offering wide-ranging archives including films, series, and documentaries from various countries with subtitles and dubbing options.

Watching a film in the theater is an experience that has its own ritual. People first search for the options and choose a film, buy the tickets, then sit in the same chair until the film has finished. The images on the curtain are on the target of their attention. However, watching television is a common act in the daily lives of people which does not require an extra effort except opening the device. Different from cinema, television always has to keep the attention of the audience. The viewer can eat or do chores while watching televisual content, even read the messages on the mobile phone. As a result, the function of sound is greater in television than cinema. It becomes "the major carrier" of the message (Ellis 1992, p.128, 129). On the other hand, televisual fiction has its own visual characteristics which is mostly based on close-ups, known as 'talking heads' (Ibid, p.131). In terms of production, television offers much more 'limited' time than cinema, which has negative results on the directional quality of television series. Besides the scarcity of time, different names can be hired as directors in a season, who obliged to protect already defined visual characteristics of the work. Following a template hinders directors to express with their own style (Bignell 2007, p.161). 
With the rise of pay-tv channels like HBO offering globally popular television series, quality television had been introduced, which was then adopted by streaming services like Netflix, Hulu, Amazon Prime Video in the last decade. According to Pearson (2007, pp. 244, 245) narrative complexity can be used as the tool for recognition of the quality television, and "the quality discourse concerning the respective cultural values of television and cinema" is about to make these two media indistinguishable.

The impact of technological progress in the recent era has also contributed to the convergence of television and cinema. All electronic devices having a screen and internet connection turned into a television screen. Television lost its throne as a domestic medium which used to gather all members of the family in the living room, after becoming pocket-size with mobile phones. When Apple Inc. had released the first iPad in 2010, tablet computer technology began to alter the entertainment industry by allowing more convenient use than personal computers. Mobile applications that were developed for phones and tablets made reaching any content possible in the quickest and customized way, as well as connecting the devices to smart TVs (Lotz 2014, p. 68). In addition, digitalized television which was released from its black box shape has been becoming thinner and smarter year by year. As a result of widescreen televisions that offer the feeling of cinematic experience at home, the 'image' has gained more significance (Weissmann 2012, p.32). As the number of streaming services increases and these services begin to dominate the entertainment industry, television companies are busy with revising televisual content to satisfy the new audience of the era who demand diversity and high quality in programming, while cinema moguls are dealing with finding new ways to bring people to back to theatres.

Streaming services have introduced new ways of production for television series which are similar to cinema films. Being freed from the charge of filling a schedule for 24 hours as 
television channels, they allow an adequate amount of time for the production processes of their original series from pre-production to post-production as a cinema film. Different from the change they provided for new ways of producing, the change in the narratives of the original contents of these services is also remarkable.

It can be argued that the genre which takes the advantage of freedom provided by streaming services mostly is 'comedy'. Comedy is the most sharp-tongued genre by allowing criticism without limits when it is combined with humor. However, in mainstream cinema films or television series comedy used to be presented in forms of romance comedies or comedy-dramas having conservative narratives which guarantees the highest ticket sales or rating results. In 1998, HBO released a comedy series named Sex and the City to attract the audience who are "young, upscale, professional women", and the series quickly became popular with its story which is unusual for traditional television channels. It contributed to an increase in the number of its subscribers (Lotz 2014, p. 234, 236). The niche audience who are users of streaming services today are being introduced with comedy series for a while that attract them with their creative narratives. In 2013, Netflix released its second original series which is a comedy-drama named Orange is The New Black questioning prison system in the USA over a group of female prisoners from different races and ethnicities. When up-to-date comedies of Netflix are searched a comedy-drama named After Life shines out with its unusual plot which is about a middle-aged man who decides to become an evil man after losing his bellowed wife to punish the people still living. Amazon Prime Video's series' The Marvelous Mrs. Maisel and Fleabag had been popular comedies of last years. Besides series, streaming services also support comedy genre by distributing stand-up comedies and independent comedy films. 
By studying the comedy series Bartu Ben (Its me, Bartu) which is one of the original series of Turkish streaming service Blu TV, the study aims to interpret the differences provided by streaming services which contributes to the transformation of comedy genre. Before studying the case, comedy genre in Turkish cinema and television will be analyzed briefly.

\section{Comedy in Cinema}

The era of cinema in Turkey between 1946 and 1981 is known as Yeşilçam (Green Pine) (Akser, 2018, p.155). It can be argued that Yeşilçam had taken the advantage of television's late arrival to Turkey when it is compared with the cinema industries of western countries (Ibid. p.157). As the television became reachable countrywide in the mid-1970s, Yeşilçam began to lose its audience and the industry had to face a financial crisis that led to the rise of sex films (Ibid. p.162). However, the production company named Arzu Film had managed to compete with television with its romance and family comedies in the era and had weakened the dominance of sex films. Director Ertem Eğilmez who is also the founder of Arzu Film made the greatest contribution to the progress of comedy genre in Yeşilçam. He gave chance to unknown actors in his films instead of working with stars, and introduced new names to the industry, like Kemal Sunal, Halit Akçatepe and Şener Şen who became leading comedy actors after Eğilmez's Hababam Sinıf (Keep on Class) in 1975 (Mutlu 2008, p.208). Eğilmez also made period/costume comedies as Süt Kardeşler in 1976 and Şabanoglu Şaban (Şaban, the Son of Şaban) in 1977 which were adaptations of traditional Turkish performing arts to cope with the upcoming crisis. In all sequels of Hababam Sinff $i$ and period comedies, Kemal Sunal used the name of 'Şaban' for all his characters. The second half of the 1970s had been the era when Sunal became the star of Yeşilçam comedies later on. With his nickname "Cow Şaban" he had 
involved in seventeen comedy films as their leading actor (Arslan 2011, p.216) and he played in eighty-two films in total.

In the early era of private television channels in Turkey, Kemal Sunal films were used in prime-time as filler programs, and they obtained a very high rating result every time they were broadcasted. Even until today, the audience's interest has never diminished. According to Tekelioğlu (2006, p.205), the success of Sunal's films are not a coincidence and all characters of these film were professionally constructed. It can be claimed that the main audience of these films are people within the urban lower and lower-middle class. The fake provincial accent of Sunal's characters' representing Anatolian people, explains his popularity. He uses slang words but never swears. He is never welcomed by elites of urban life and he used to struggle to survive in the city. Despite his foolishness, in the beginning, he turns into a smart man all of a sudden and defeats the ones tiring him. And he takes the revenge of his audience too (Ibid. p.207). In the era of late Yeşilcam which began after the coup in 1980, sex films were banned and popular films about gender issues were made besides family melodramas, romantic comedies, and action-adventure films (Savaş 2011, p.204). In 1988, Ertem Eğilmez made a self-reflexive comedy named Arabesk which was a parody involving all clichés of "Yeşilçam melodramas, particularly of arabesk singer films". In 1999, Arabesk's scriptwriter Gani Müjde had written and directed another Yeşilçam parody named Kahpe Bizans (Harlot Byzantium) which teases with period action films (Ibid. P. 162). 1999 also was the year, when Kemal Sunal acted for the last time in a comedy film named Propaganda (Dir. Sinan Çetin) before he died next year while he was working for his new film.

Cinema in Turkey had been entered into a new era which is defined as 'new Turkish cinema' with official regulations on canceling the censorship and starting a financial support 
system (Akser 2018, p.163). In this new era "parody has become a common way of incorporating the Yeşilçam tradition while also maintaining a seemingly ironic distance from it"' (Savaş 2011, p.167). In 2000, director Tunç Başaran made a satirical comedy criticizing music and television in Turkey industry named Abuzer Kadaylf which was about an academician who pretends to be an arabesk star for his research. Popular Turkish comedian Cem Yılmaz wrote and played in a science fiction parody G.O.R.A. (Dir. Ömer Faruk Sorak) in 2004 which includes a character claiming that he was a former science fiction writer in Yeşilçam. Two years later another science fiction parody Dünyayı Kurtaran Adamın Oğlu (Son of the Man Who Saved the World, Dir.

Kartal Tibet) was released which was a sequel of action film named Dünyayı Kurtaran Adam (The Man Who Saved The World, dir. Çetin İnanç). In 2014, Cem Yılmaz made a comedy-drama named Pek Yakında (Coming Soon) about a group of people including losers of Yeşilçam who try to make a science-fiction melodrama in Yeşilcam style.

In the last two decades, domestic cinema films have been dominating the box-office in Turkey. When the domestic films released in the last twenty years are listed according to their ticket sales, it can be seen that the genres of the first hundred films distribute as below:

TOP 100 TICKET SELLING TURKISH FILMS, 2000-2019

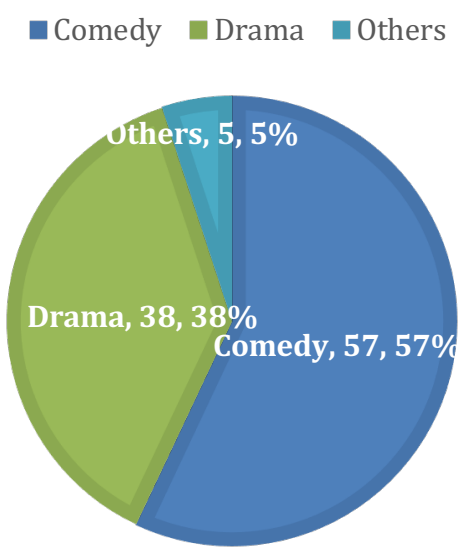


With the result of 57 percent comedy genre protects its popularity in mainstream Turkish cinema. Most of the blockbuster comedies had sequels in the last twenty year, which are:

- Vizontele I-II (2001-2003)

- Hababam Sinifi I-II-III (2004-2005-2006)

- Maskeli Beşler I-II-III (2005-2007-2008)

- Organize İşler I-II (2005-2019)

- Kutsal Damacana I-II (2007-2009)

- Çılgın Dersane I-II-III (2007-2008-2014)

- Recep Ivedik I-II-III-IV-V-VI (2008-2009-2010-2014-2017-2019)

- Kolpaçino I-II-II (2009-2011-2016)

- Eyyvah Eyvah I-II-III (2010-2011-2014)

- Çalgl Çengi I-II (2010-2017)

- Çakallarla Dans I-II-III-IV-V (2010-2012-2014-2016-2018)

- Dügün Dernek I-II (2013-2015)

Among all blockbuster comedies, Recep Ivedik (Dir. Togan Gökbakar) had reached the highest ticket sales of all times and its sequels broke records every year they were released. Before first Recep Ivedik film met the audience, Şahan Gökbakar who is the writer and star of the film become known with a comedy show on television named 'Dikkat Şahan Çıkabilir' which was broadcasted in TV8 in 2005. The show was an "anti-media sketch show" teasing television people, formats, and the 'mentality' of the television industry (Pekman \& Tüzün 2012, p.12). Recep Ivedik was one of the characters of the show who became very popular with the contribution of Youtube videos. As Akser (2013, p.135) points out he "turned into a cultural phenomenon",

His famous lines created what we can call a subculture. Recep was loved by millions, his laughing voice became a ring tone in cell phones and he even had an iPhone application quoting his lines. Recep Ivedik as a character embraces the cultural diversity and problems of dislocated immigrant rural youths living in the suburbs of big cities. He is uneducated, unemployed, vulgar yet honest, 
modest, friendly and with some common sense and the belief that he can win the day.

On the other hand, what he attacks with jealousy and resentment is cultural capital. He opposes the distinction caused by social status, rather than economic status. Like the characters of Kemal Sunal, Recep Ivedik is not an idealized or oppressed person who ignores his desires. They both challenge their competitors and play with them despite their own disadvantages. The way of their resistance to dominant values seems to be the source of the popular pleasure they have created (Aydoğan 2020, p.603).

Different from mainstream comedies, the arthouse cinema in Turkey began to introduce comedy films that focus on modern age individuals who suffer loneliness in urban life. After Ramim Matin’s Son Çıkış (Siren’s Call, 2017), Tolga Karaçelik's Kelebekler (Butterflies) which had been awarded in Sundance in 2018 was released and it followed by Kıvanç Sezer's Küçük Şeyler (Little Things) in 2019.
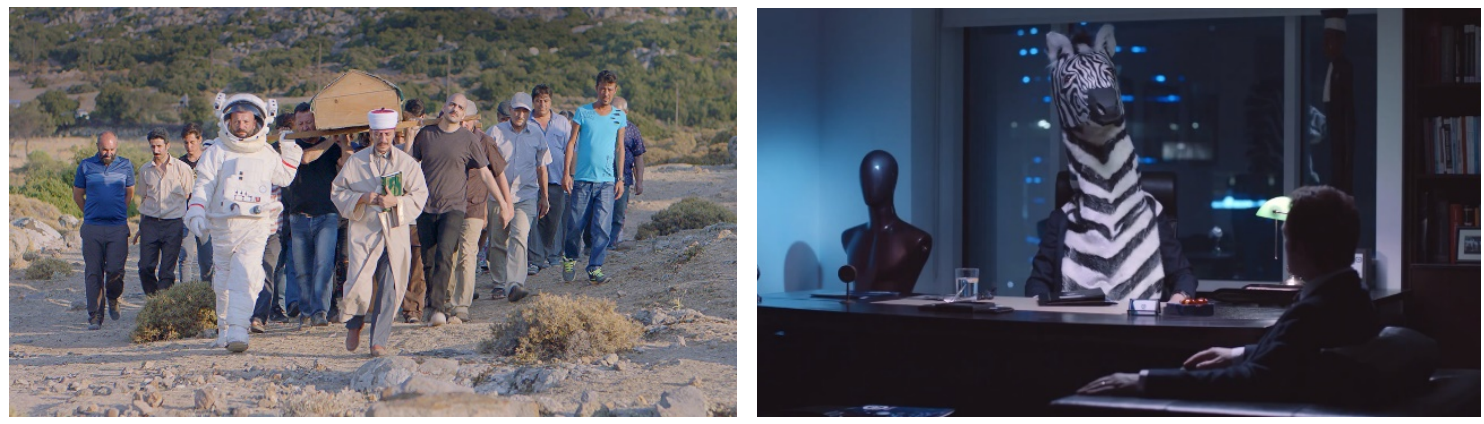

Figure 1: Still from Kelebekler (Butterflies) / Still from Küçük Şeyler (Little Things)

(Source: Kelebekler https://www.youtube.com/watch?v=5haJDNWiqUY, Küçük Şeyler https://www.youtube.com/watch?v=7t1VIPjmCCM ) 


\section{Comedy on Television}

In the early era of television in Turkey, which can be defined as the monopoly of TRT (Turkish Radio and Television Corporation) which is between the years 1968 to 1991, local series used to be literary adaptations mostly melodramas. The first local comedy series was a sitcom Kaynanalar (Mothers in Law) in 1974 which was about class conflicts between two families. Even though it managed to get the attention of the audience by representing familiar cultures, local series became the focus of taste of masses with Perihan Abla (Sister Perihan) in 1986 which was about a single middle-aged woman who helps everyone in her neighborhood to solve their problem (Tanrı̈ver 2011, p. 47).

When the private channels began to arrive in 1991, audience in Turkey were exposed to noisy schedules full of game shows, reality shows, talk shows, magazine and music programs which made the series became unpopular for a while. However, the trend began to change on behalf of series - mostly family dramas - in the late 1990s, and local series conquered the screen in the early 2000s and has been protecting their dominance still today. According to Mutlu (2008, p.107) television is a family medium, and televisual narratives are built on 'family'. In the center of the narrations, there are also families in two ways; real families or television families - communities consist of people working in the same place like the police station, hospital, news agency, even people living in the same district - These communities include characters functioning as the real family figures. There is always a father figure, naughty kids, easygoing kids, and someone who undertakes the role of mother. If there is not a mother, lack of her is always emphasized.

In the 1990 s, the common feeling about social transformation in the country was pessimism and yearning for the modest times of the past. Comedy - family dramas of TRT had used to promote 
solidarity, wisdom, and modesty in the 1990s (Çelenk 2005, p.145, 146). One of these comedydrama series is Şaşıfelek Çıkmazı (Cross-eyed Fate Street) which was about middle-class people living the same neighborhood. However, this series differs from other TRT series and even most of the private channel series with its modernist discourse on gender.

While TRT dramas were trying to console the audience who suffer nostalgia, private television channels were broadcasting foreign films and series in Turkish dubbing which were appreciated by the audience. Even though the foreign series used to be interpreted as 'distant' for the local audience due to reflecting different cultures, many foreign series were followed by masses as a result of their themes such as love, deception, and family relations which are universal. An American sitcom Married with Children which criticizes society and family values had been welcomed by the audience who wish to see realistic characters on television different from the ones in TRT whom all have proper qualifications. In the early years of the 2000 s, number of sitcoms increased in private channels after Dadı (Nanny) and Tatlı Hayat (Sweet Life) which were adaptations of America based ones The Nanny (1993) and The Jeffersons (1975) had reached the highest rating results (Ibid. p.297, 304).

In 2004, a new sitcom named Avrupa Yakası (European Side - ATV) which has a story based on the conflicts between a modern young woman who works in a magazine and her traditionalist bourgeois family began to be broadcasted. Avrupa Yakası had used to be on the top of the rating lists and it can be defined as the 'breaking point' of local sitcoms. Even though the humor is first built on the relationships among elite employees of the magazine, then the direction of humor turns to class conflict, represented over provincial characters which are added as new employees or relatives (Çelenk 2014, p.200).

In the following years, melodramas began to dominate prime time which resulted in disappearance of sitcoms. A few comedy - family dramas like Ekmek Teknesi (Bread and Butter 
- 2002, ATV), Yabancı Damat (Foreign Groom - 2004, Kanal D), Canım Ailem (2008, ATV)

and Aramızda Kalsin (Between Us - 2013, Star TV) managed to survive in rating wars.

When the second decade of the 2000s has arrived, television in Turkey began to get more conservative year by year with the rising censorship of RTÜK (Radio and Television Supreme Council). Moreover, durations of the series increased and reached almost three hours due to advertising strategies of television channels which aim to keep the audience as long as possible in front of television. Besides formal restrictions and financial policies of the channels, the internet had also given rise to the fragmentation audience. As the younger audience preferred to consume audiovisual content via their mobiles or personal computers, they abandoned watching scheduled television programs. On the other hand, a group of audience who wish to reach diverse content began to use the internet as the source of foreign films and series - mostly via illegal way.

Audience in Turkey had witnessed to the transformation of a sitcom with its transfer from a VOD channel to a mainstream channel. In 2008, a Turkish VOD service Digiturk, began to broadcast a local sitcom named Bir Kadın Bir Erkek (One Woman One Man) which was an adaptation of a French sitcom Un Gars Une Fille. It was about the relation of an unmarried young couple who were sharing the same flat. Due to its unusual characters and stories that were told in each episode, the audience found it very brave even provocative and it had a huge fan during all its 416 episodes. After this series became very popular especially among the young audience, the national TV channel Star TV bought it in 2012 and started to broadcast it under the name of Bir Erkek Bir Kadin (One Man One Woman) for three seasons, after prime time. However, the series started to become conservative very soon. The couple got married, their adventures which make the audience have fun started to become ordinary. After three seasons in 
Star TV, it was transferred to Fox TV with the name of Bir Erkek Bir Kadın İki Çocuk (One Man One Woman Two Children) and the couple had twins. Unsurprisingly its audience did not find adventures of these inexperienced parents interesting anymore and the series had canceled. In 2011, TRT introduced an extraordinary comedy series Leyla ile Mecnun (Leyla and Mecnun) which borrowed its name from an Arabic legend based on a love story. The series built its humor on the despair of an unemployed young man who has close friends as unlucky as him in his neighborhood. Besides the main character, his friends are not good at communicating with women too, and they all used to suffer love pain. These men with no job and no girlfriend had been embraced by the young male audience, and the series had its loyal fans. What made the series distinctive was using 'pain' in a comedy (Akınerdem 2013, p.43). It can be argued that the change in the sense of humor which turned its face to 'absurd' had primarily shaped by Turkish humor magazines. TRT's strategy on supporting absurd comedy against the traditional humor of mainstream channels can be interpreted as surprising (Tekelioğlu 2017, p.32). The sense of humor of these humor magazines depends on not concerning political correctness and teasing with excessive self-regarding (Favaro \& Akşit 2016, p.193). Despite their insufficient resumes and disappointed hearts, the trio of Leyla ile Mecnun used to condemn people who take themselves too seriously. Excessive self-regarding which causes arrogance is unacceptable in the series. As the orientation of middle-class young people with urban life has become apparent since 2010, the humor produced and consumed by these people began to shape the humor in some Turkish television series, humor magazines, and web sites (Ibid, p.197). In 2012, another a self-reflective comedy series named Işsler Güçler whose target audience was similar with Leyla ile Mecnun released by Star TV. It was about the struggle of three young actors who are unable to have the roles they dream, and with words of the series' director Selçuk Aydemir, is a "satire of the whole TV show production system" in Turkey. In the same year, Kanal D released a new 
sitcom Yalan Dünya (False World) written by Gülse Birsel who is also the writer of Avrupa Yakasl which had great success in ratings and spanned 190 episodes in five seasons. The humor in the series is built on the conflict between a group of actors and their nouveau riche neighbors living in the same building. The discourse of the series is determined by the opposition of traditional and modern once again as in Avrupa Yakast. The series also has self-reflectivity, it teases with the television industry in Turkey, by mimicking an Anatolia based melodrama which the actors in the building are playing together.

After the game-changer comedy film Recep Ivedik was released in 2008 and its sequels later on, comedy series with 'macho' characters and conservative narrations referring to patriarchal codes of the society begin to appear in the following years: Türk Mall (Made in Turkey - 2010, Show TV), Alemin Kralı (King of the Jungle - 2011, ATV, Ankara'nın Dikmeni (2014, Kanal D) and Şevkat Yerimdar (2017, Kanal D). The change in the profile of television audience becomes clear with the tendency in the mainstream's sense of humor towards 'coarse'. Humor in these comedy series leans to the attack of the protagonist who is from periphery to the world in the center and its residents (Tekelioğlu 2017, p.18, 19).

Recently, comedy series left traditional television to weekly sketch comedy shows. Their absence can be explained with the reasons which were also mentioned before for the explanation of fragmentation of audience. The genre which gets most impacted by censorship is comedy. As Mutlu (2008, p.179) points out, "comedy mess with regularity, continuity and conformity, pokes the fears and solicitudes of both individual and society, deals with lie and hypocrisy, and always stands beyond the border." In 2017, Star TV broadcasted a satirical comedy of Kemal Sunal named Kibar Feyzo (Polite Feyzo) with a censored version. The name of Sunal's character in the film is Feyzo who is one of the Anatolian villagers exploited by the landlord of the village. 
Private television channels had been using Kemal Sunal films to fill their schedules since the 1990s, and the slang words in these films used to be censored. However, a scene in which Feyzo talks about the strikes he saw in Istanbul, the frames involving a street wall written on it as "Workers are brothers, bosses are traitor!" censored for the first time by blurring the word of 'traitor' (Koloğlu 2017).

\section{Tragedy of a Minor Celebrity: Bartu Ben}

Director Tolga Karaçelik collaborated with Bartu Küçükçağlayan once again after the film Kelebekler (Butterflies) for a comedy series named Bartu Ben (Its me, Bartu) that met the audience via Turkish streaming service Blu TV. Küçükçağlayan is also the writer of the series plays as himself in the story focusing on his career which is not going well. Bartu in the series, is thirty-five years old actor who has not been cast for a long time after his role in Yalan Dünya (False World). He has financial problems and even cannot pay his rent. He used to visit his agent Şermin (Sezin Bozac1) to make her find him a role which he would like. However, he rejects all offers form television series which he could earn money. One night he tries to seduce a young woman at the bar without recognizing that she was his cousin Gizem (Nazlı Bulum). Gizem introduces herself and tells him that she is going to study at the department of acting in university, and also looking for an apartment. Next day Bartu meets his uncle (Müfit Karacan) who is a widowed man. His uncle was a very talkative man, he talks about how they had a party with prostitutes. Bartu tries to get rid of his cousin and uncle as soon as possible. When he learns that his landlord has decided to sell his apartment, his mood gets worse. He cannot rent a new apartment and gets confused. In those days, his uncle visits him with Gizem and tells him about his plan on buying his apartment where he could continue to stay with her cousin. Bartu does not want to lose his privacy and refuses his offer. However, in the following days, his life gets 
worse, he empties the house and sells his furniture. He begins to stay in the apartment of his friend who is gay. A man who used to visit his friend molests him and makes him get furious. Soon after he changes his mind and accepts his uncle's offer about buying the apartment. He moves back and begins to live with his cousin. His uncle organizes another party with prostitutes and forces Bartu to join him. However, the man gets a heart attack during the orgy. While he stays in the hospital to recover in the following days, Gizem is offered a role in a television series as the leading character and the supporting role who is a gay hairdresser named $\mathrm{Kiz}$ Hüseyin (Girl Hüseyin) is offered to Bartu. After all his failures, Bartu accepts the role and begins to shoot the over cliché action - melodrama in a great disappointment. Bartu is resembles his career to paragliding and says "they are both spiraling down from the top". In the auditions he loses his all self-confidence and begins to act like a fool then argues with the cast directors in the end. His agent insists him to be close to the public and sympathetic, to create social media profiles and have a hair transplant. He refuses all. He does not want to attend a talk show and says:

What am I going to tell them on TV when they ask "how it is going?" Am I going to say 'Like shit.' Am I going to say, the TV series are like shit, game shows stink? Because you want to shoot shitty stuff between ads, we are used up?

He cannot cope with his existential crisis and questions everything; he even asks weird questions to the janitor of his apartment when he is giving the garbage. Even though he is right about his critiques about the television industry, he has a problem with being an adult. His close friends blame him for acting spoiled as the son of a celebrity. He regrets about how people became impassive in the country. 
Bombs going off. We are stuck in our homes. And I find myself at a kebab shop next day, with a menu in my hand, trying to decide whether I should get a shish kebab or a lamb steak? I don't want to be there.

However, he is also a self-centered person, takes himself very seriously. He is unhappy about being 'a minor celebrity' and wishes to be recognized and welcomed by others. He says to his agent while he is complaining as always "I am unemployed, I am public."

\section{Wearing Small Size Shoes}

One day he meets his actor friend Öner Erkan whom he worked within Yalan Dünya. Erkan has been in the cast of a television series which is an action drama named Çukur (Pit, Dir. Sinan Öztürk) since 2017. Çukur is based on the years-long battle between two mafia families living in the periphery. As a result of its genre, it involves excessive use of violence and masculine discourse. Bartu asks Öner about how he could bear to be in 'that kind of' series and Öner answers him as:

It's like I have to wear one size small shoes all the time outside. You take them out at home and wear slippers in summer. You play in a film with barefoot. I am trying to balance it bro...

Despite Erkan's honest answer, the series becomes a little didactic when it criticizes the pointless facts of the television industry. While shooting the action-melodrama which Bartu plays Kız Hüseyin, the main character of the series argues with the director about using swear in the scene he fights with his enemy. He complains about censorship on television about swearwords which disrupts the sense of reality. Or Bartu's gay friend who joins an audition for a gay character in a television series and complains when he cannot get the role by saying "Real queer people don't have a place in this market. Gays are played by not even people but by vegetable". 
Even though "recent Turkish cinema demonstrated an uncanny ability for the realistic representation of LGBT characters in complex ways" such as Güneşi Gördüm (I Saw the Sun, 2009, Dir. Mahsun Kırmızıgül), Zenne (Zenne, The Male Dancer, 2012, Dir. M. Caner Alper and Mehmet Binay) and Nar (Pomegranate, 2011, Dir. Ümit Ünal) (Akser 2016, p.7), television series still prefers to ignore LGBT characters. They rarely appear on traditional television and if they do, they are represented as supporting characters who are 'asexual, sharp-tongued' stereotypes like Cücü (İbrahim Selim) in Güllerin Savaşı (War of Roses 2014) or Koriş (Onur Büyüktopçu) in Kirallk Aşk (Love for Rent 2015).
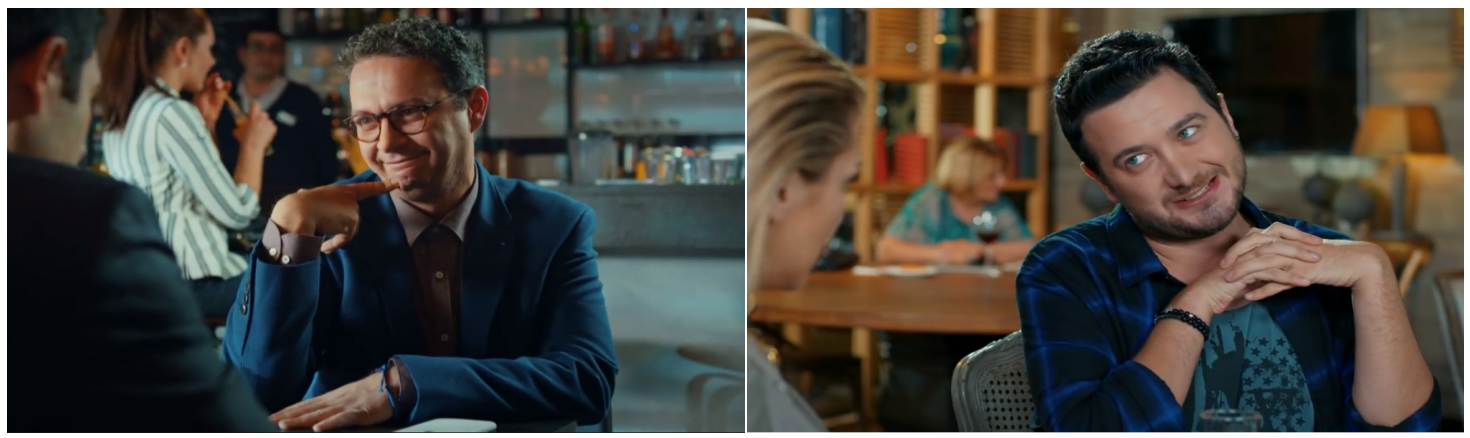

Figure 2: Cücü in Güllerin Savaşı and Koriş in Kiralık Aşk

(Source: Kiralık Aşk https://www.youtube.com/watch?v=FCkuKZTX2sQ, Güllerin Savaş1 https://www.youtube.com/watch?v=U115e6x38mY)

When these two examples of gay characters are considered, it can be seen that their way of representation is also a way of teasing with homosexuality and it is used as the source of 'fun', the clown in the narrative. The effeminacy in their body language is over emphasized almost in ridiculous way, and these characters are marginalized as the 'other' in the narrative who behave as weird humans different from everyone else around them. 
In Bartu Ben, one of two close friends of Bartu is a young gay who uses a nickname 'Mercimek' (Okan Urun). He is a foul-weather friend and honest person, supporting Bartu to overcome his depression. Mercimek is depicted more realistically as a human without ignoring his sexuality, however, representation of the gay character in Bartu Ben is problematic due to his resemblance with gay stereotypes of traditional television series. Even though Mercimek has sexual affairs with different men during the series, he is represented as effeminate gay stereotypes of television who used to function as the source of 'fun'. With the role of 'K1z Hüseyin' which Bartu accepts to play unwillingly, the series criticizes the television industry's attitude towards LGBT characters' representation. At this point, it becomes clearer that, the series itself also does not have a three-dimensional gay character. Except Mercimek, the series had prioritized 'realism' while constructing its other characters. However, over emphasis of the gay best friend's effeminacy contradicts with the characteristics of the series, does not contribute to the narrative, even disrupts its coherence.
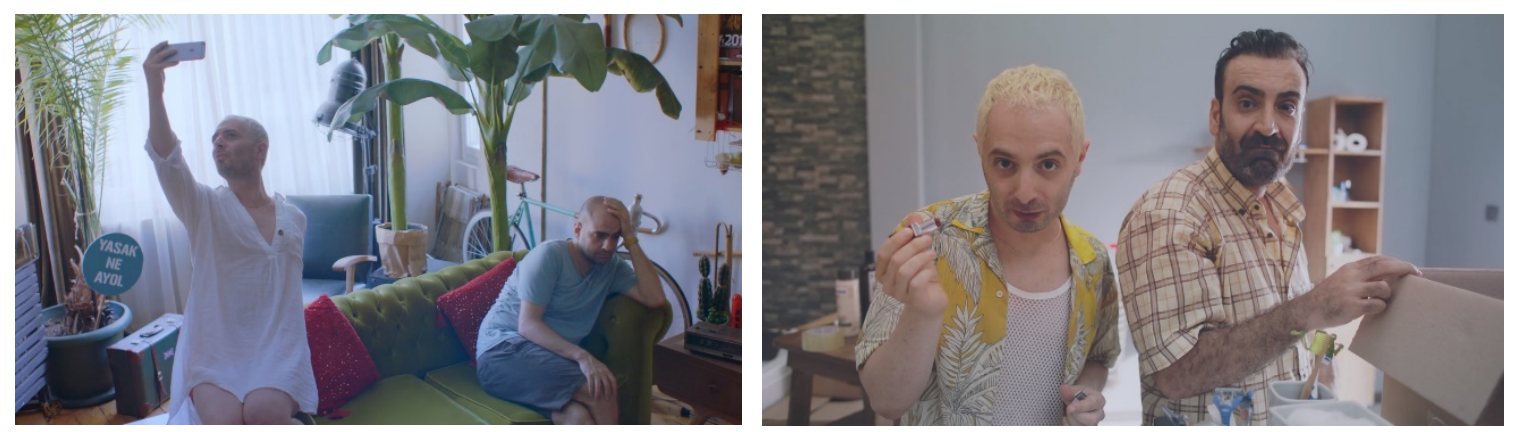

Figure 3: 'Mercimek' in Bartu Ben (Source: Blutv.com)

On the other hand, the series takes advantage of its medium about sexuality and uses it in a way that is not possible to be shown or vocalize in traditional television in Turkey. Bartu begins to cry under the sheet during the oral sex with a young woman. He tells about his desperateness 
caused by losing his apartment and having only one chance which is living with his cousin Gizem and taking care of her as a mother. The scene is an extraordinary example with its surprise mood change of the characters, as well as its composition contributing the humor.
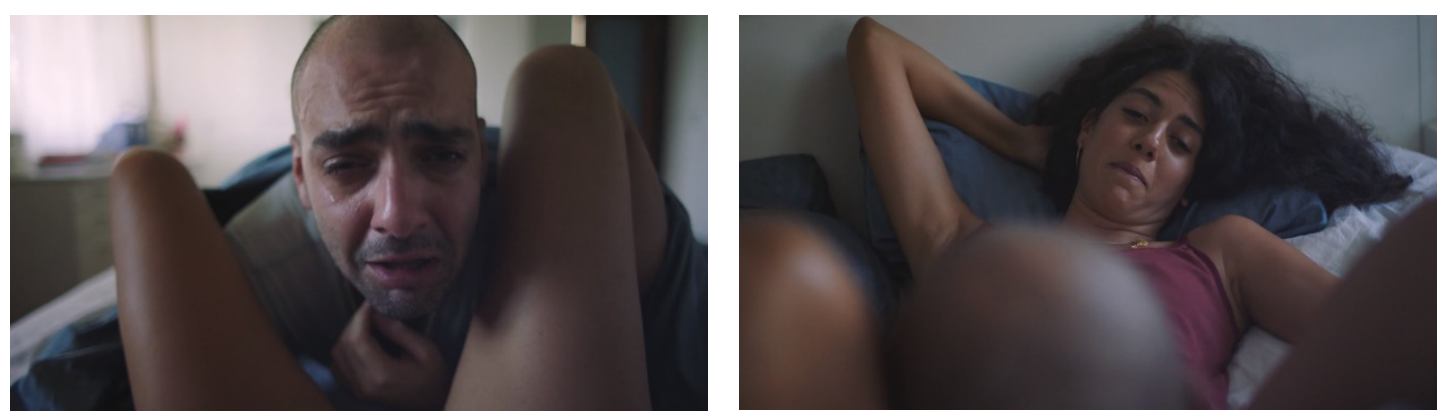

Figure 4: Bartu's Tears (Source: Blutv.com)

Moreover, the cousin Gizem who is 18 years old, annoys Bartu by telling him the 'threesome' she had with her new boyfriend and another young man. Gizem is also unique character for being a young woman who does not hesitate follow her desires and talk about them.

Finally, in terms of representation of family, Bartu Ben reflects a progressive perspective by depicting a core family involving only a father and his young adult daughter both rejecting the conventional family values. The father in his fifties confesses the disappointment about his past spent as a family man for years and shares the regret of adopting the roles which society had assigned to him. 


\section{Conclusion}

Self-reflective comedy series are not a new discovery, and the hypocrisy in television industry had been criticized before in television series like Yalan Dünya and İşler Güçler. Constructing the narrative on urban losers is also riskless in comedy genre if the target audience are mostly the young people. Bartu Ben differs from other self-reflective series by involving a 'real' actor who plays as himself. Furthermore, what Bartu Ben offers different from the television comedies is not limited to the use of sexuality despite its frequent presence. The emphasis on sexuality vanishes under the shadow of all existential crises of all characters. And with its emphasis on dysfunctional family, the series also differs from traditional television comedies. However, it fails in terms of representation of its gay character which is far from being different from stereotypes of television.

When the medium's impact on the characteristics of the content is considered, it can be claimed that what Blu TV tries to do by offering Bartu Ben is highlighting its policy and position which is in opposition to traditional television. Moreover, comedy is the genre that requires freedom at most from the first moment of construction of its narrative. In conclusion, the freedom of streaming services is vital for comedy series in Turkey, due to the constraints of today's television excluding unusually created contents.

\section{BIBLIOGRAPHY}

Akser, M. (2016) Changing LGBT Narratives in Turkish Cinema in Reconstruction 16(2). Regionalism, Regional Identity and Queer Asian Cinema. online.

Akser, M. (2018) Locating Turkish Cinema Between Populist Tendencies and Art Cinema. In A. Magnan-Park, G. Marchetti, S. Tan (Eds.), The Palgrave Handbook of Asian Cinema, (pp.151170). Basingstoke: Palgrave Macmillan. 
Akser, M. (2013) Recep Ivedik Review In E. Atakav ed. Directory of world cinema: turkey London: Intellect.

Akser, M. (2013) Blockbusters in Turkish Cinema In E. Atakav ed. Directory of World Cinema: Turkey. London: Intellect.

Akınerdem, F. (2013) Turkish Television Series: An Overview in Perspectives - Political Analysis and Commentary from Turkey, 4(13), 41-43.

Arslan, S. (2011). Cinema in turkey: a new critical history. New York: Oxford University Press.

Aydoğan, D. (2020). Melodram'dan Anti-Melodram'a; Popüler Türk Sineması'nda İktidar, Arzu ve Kayg1 Söyleminin Dönüşümü, Recep İvedik Örneği. From Melodrama to Anti-Melodrama; Transformation of Discourse of Power, Desire and Anxiety in Popular Turkish Cinema, Case of Recep İvedik SineFilozofi , (589-610) . DOI: 10.31122/sinefilozofi.675224

Behlil, M. (2020). Turkey: Transnational Dimensions of a Large National Film Industry. In L. Papadimitriou and A. Grgić (Eds.) Contemporary Balkan Cinema: Transnational Exchanges and Global Circuits. Edinburgh University Press.

Bignell, J. (2007). Seeing and knowing: reflexivity and quality. In J. McCabe and K. Akass (Eds.) Quality TV:Contemporary American Television and Beyond. (158-170). London:

I.B.Tauris

“Comedy show satirizes TV series sector” 26 July 2012

https://www.hurriyetdailynews.com/comedy-show-satirizes-tv-series-sector-26336

Çelenk, S. (2014). Kamp Ateşi Sönüyor mu? In D. B. Kejanlığlu, T. Taş, O. Taş, E. Çaylı, M. Yerbekov. (Eds.) İletişim, Anlam, Arayış: Erol Mutlu'ya Armağan. Ankara: Ütopya Yayınevi

Çelenk, S. (2005). Televizyon, Temsil, Kültür: 90’lı Yıllarda Sosyokültürel İklim ve Televizyon Içerikleri. Ankara: Ütopya Yayınları

Ellis, J. (1992). Visible fictions: cinema: television: video. London: Routledge. 
Favaro, A. \& Akşit, O. O. (2016). Cool'dan Kitsch'e Kendini Ciddiye Almamanın Dayanılmaz Hafifliği: 've Sinem'in Canı Çok Sıkılıyor'. Medya ve Mizah (pp.193-210), Ankara: Nobel Yayın Dağıtım.

Koloğlu, S. (2017) Kemal Sunal'a İlginç Sansür 31.07.2017

https://www.milliyet.com.tr/cadde/sina-kologlu/kemal-sunal-a-ilginc-sansur-2494269

Lotz, A.D. (2014). The Television Will Be Revolutionized. New York: New York University Press.

Mutlu, E. (2008). Televizyonu Anlamak. Ankara: Ayraç Yayınları.

Pearson, R. (2007). Lost in Transition: From Post-Network to Post-Television. In J. McCabe and K. Akass (Eds.). Quality TV: Contemporary American Television and Beyond, (pp.239-256). London: I.B.Tauris.

Pekman, P. \& Tüzün, A. (2012). Recep İvedik: ‘Kahraman'dan ‘Ürün’e. Galatasaray Üniversitesi İletişim Dergisi, (17), 9-28.

Tanrı̈ver-Uğur, H. (2011). Türkiye'de televizyon yayıncılı̆̆ı, İstanbul: İstanbul Ticaret Odas1 Yayınlar1.

Tekelioğlu, O. (2006). Pop yazılar: varoştan merkeze yürüyen halk zevki. İstanbul: Telos Yayınlar1.

Tekelioğlu, O. (2017). Televizyon halleri: dizi dizi türkiye. İstanbul: Habitus Yayınları.

Türk Filmleri Seyirci Rekoru - İlk 100 (1989'dan Günümüze)" https://boxofficeturkiye.com/tumzaman/?tm=1989tr

Weissmann, E. (2012). Transnational television drama: special relations and mutual influence between the US and UK. Basingstoke: Palgrave Macmillan. 